ographical Magazine

\title{
Sketch of South-western Turkomania
}

\section{Paul M. Lessar}

To cite this article: M. Paul M. Lessar (1885) Sketch of South-western Turkomania, Scottish Geographical Magazine, 1:5, 157-168, DOI: 10.1080/14702548508521080

To link to this article: http://dx.doi.org/10.1080/14702548508521080

$$
\text { 曲 Published online: } 30 \text { Jan } 2008 .
$$

Submit your article to this journal

III Article views: 8

Q View related articles ¿ 


\title{
SKETCH OF SOUTH-WESTERN TURKOMANIA. ${ }^{1}$
}

\author{
BY M. PAUL M. LESSAR.
}

\section{Translated from the Russian by H. A. WEBSTER. ${ }^{2}$}

THIS district has no general name, either among the Turkomans who occupy its frontiers, or among the neighbouring inhabitants. In recent times, some English geographers have begun to call it Badkhyz, as a proof of its belonging to Afghanistan ; ${ }^{3}$ but that this is erroneous can easily be shown, even from English sources. Badkhyz is the mountain district between the rivers Kushk and Kash. ${ }^{4}$ The district between the Murg-ab and Heri-rud is most correctly designated after its ethnographical characteristics-Land of the Saryks and Salors, or, in more general terms, South-western Turkomania. As I have previously mentioned, little was known about this country up till 1881. The English travellers, Shakespeare and Abbot, in 1840 and 1841, advanced by the great caravan route from Herat to Merv; General Grodekoff crossed the Paropamisus Mountains to the east of the river Kushk; N. G. Petrusevich, exploring North-east Khorassan, proceeded along the Heri-rud ; but not a single European explorer visited the district between the rivers, and among the inhabitants of the surrounding country none knew the roads except the sirdars at the head of robber bands. For the exploration of South-west Turkomania, I undertook two journeys in 1882, and one in the beginning of the next year, immediately after the capture of Merv by our forces. Besides, commencing with the autumn of 1882, the following persons arrived there. According to the statement of the Persian Khan in Serakhs, after my first journey, in April 1882, Colonel Stewart, on the conclusion of his labours in Seistan, advanced to Mosyn-abad, and from thence went to Pesh-robat, Gurlen, and Islim-chishme (the latter syllable is sometimes given as chasma), returning by the same route. An account of his journey, however, has not yet been printed. Also, in the autumn of 1882 , the same road was traversed by two Russian explorers-Captain Gladysheff, who determined astronomical positions, and Lieutenant Khabaloff, who carried out a survey of the route. According to information communicated by Khabaloff, the explorers advanced from Mosyn-abad to Bengi-keriz, and crossed by a difficult route over the Borkhut Mountains, near the source of the Yaki-Tut (to the west of the Pass Khombou and

${ }_{1}$ Yugo-Zapadnaya Turkmeniya: Zemli Sarykoff $i$ Saloroff in Iyvyestiya Imp. Russk. Geogr. Obshchestva. Tom. xxi., 1885. Read before the Imperial Geographical Bociety 7th (19th) December 1884.

2 'The best thanks of the Editors are due to M. Lessar, who has most obligingly corrected the proof of the translation.

3 Vide Sir H. Rawlinson's map, attached to M. Lessar's second journey in the Turkoman country, Proceedings of the Royal Geographical Society, January 1883.

4 Compare the map Turkestan, by Walker, fifth edition. 
Karuan-ashan); they next proceeded to Kizil-bulak (named by their guide, Tulan-chishme), and thence towards Ak-robat; but the guide did not know how to find this place, and led them across Adam-elan to Serakhs, in the district between Murg-ab and Heri-rud; one point, Melek-heiran-chishme, was determined astronomically. Finally, in April next year, Charykoff, a diplomatic agent under the General-Governor of Turkestan, proceeded along the Heri-rud. From Serakhs, to a point of 10 versts $\left(6 \frac{1}{2}\right.$ miles) south of Zulfagar-Derbend (Zulfikar), he travelled along the river, and then by Keriz-Iliyas and Soutli Pass, he crossed into Khorassan, near the junction of the Jam into the Heri-rud.

BoUNDARIES.-The boundaries of South-west Turkomania are :-(1) on the north, the Merv oasis ; (2) on the east, the Murg-ab, the land of the Jemshidis, the river Kushk to the south from Chil-dukhter, ${ }^{1}$ and the hills bordering this river on the east ; (3) on the south, the Borkhut Mountains ; and (4) on the west, the river Heri-rud, separating Turkomania from Persia. The whole region measures 250 versts (165 miles) from north to south, and on an average about 100 versts in the transverse direction.

Character of the District.-The Borkhut Mountains are a prolongation of the Sefid-Kukh (Safid-Kuh), separated from the main chain by a considerable depression (between the Ardevan and Karuan-ashan Passes), in which there are, properly speaking, no mountains, but only two ranges of hills, with soft soil, across which are roads having even at present gradients not steeper than 0.02 ( 1 in 50). Such a pass is Karuan-ashan.

Further west, the ridge increases in height as it approaches the river. Its altitude is from 3000 to 4000 feet; it is composed of hard sandstones ; and its slopes are steeper, but still there are, in very many places, passes accessible, with few exceptions, for wheeled traffic. In a deep ravine in the Borkhut Mountains, which continue into Persia, flows the Heri-rud; the mountains again sink towards Meshed (Mesh-hed); and their continuation further west forms the Alla-dagh chain.

The Borkhut Mountains are the principal branch of the Paropamisus, going on to unite with Elburs; the more southern branches, near the Heri-rud, marked on some maps as the principal range, in reality are only a series of hills of very little importance on the route from Karuan-ashan to Shebesh, and on the road to Kusan, a tract of quite level ground.

Near $36^{\circ} \mathrm{N}$. lat, the clay bairs (hills) of Elbirin-kyr divide South-west Turkomania into two portions, very different in character, vegetation, and climate. Those hills, as is indicated by the very name kyr, consist of clayey elevations rising 2000 feet above the sea-level. Beginning with bluffs on the banks of the Heri-rud, they run almost in a straight line from west to east; curve round Lake Er-oilan; and, after that, change into lines of separate hills (kyrs) scattered in disorder over the rest of the

1 Other spellings of the first part are $C h i h l$ and Chahil. 
country up to the Kushk. To the east of Er-oilan, these elevations are almost parallel, and rise 50 or more sazhen (350 feet) above the surrounding country.

In this portion there is no definite slope observable in any direction; on the other hand, the triangle, having as its base the Borkhut Mountains from Khombou to Ardevan, and its apex at Chemen-i-bid, clearly forms part of the river Kushk basin. Two affluents of this river, each about 100 versts in length, previously unknown, were examined by me. One begins near Khombou, and the other near Gurlen; and they unite under the name of the Egry-gyok, and fall into the Kushk near Chemen-i-bid. The whole triangle consists of valleys beginning in the slope of the Borkhut Mountains, and drained by those leading streamlets; the spaces between the valleys form a slightly hilly region, gradually descending from the Borkhut to the north. The western portion of the southern half has a slope to the Heri-rud; some of the deep ravines stretch for 10 to 15 versts (6 to 10 miles) from the river inwards. The water-parting of the basins of the Heri-rud and the Murg-ab is formed, not by the steep bluffs near the banks of the former stream, but by the low hills behind them, which extend from the end of the Borkhut Mountains, near Keriz-Iliyas, by Kungryu-eli Adam-elan to the ruin of the bridge of Pul-i-Khatun. In general, the whole southern half is an undulating district, a series of heights and hollows; the soil is everywhere a sandy clay, overgrown with thorns and steppe-grass; sand occurs only in certain places and in very limited quantity, clearly produced by the disintegration of the kyrs.

The northern slope of the Elbirin-kyr has at first the same appearance as the southern. Deep ravines run from the summit of the heights, in general northwards; then follow rows of separate heights, which become always lower and lower; towards the well Koyun-Kui, but only at intervals, are separate kyrs; the mixture of sand becomes always greater and greater, and finally the country passes into a sandy desert like that of Kara-Kum (boundaries shown on the accompanying map). On the south it is bounded by a line curving from bairs at Doulet-abad to Kalei-Mor on the Kushk ; on the west the sands extend to the road from Serakhs to Merv, and cut across it in a few places, and, passing to the roads for Karry-Bend and Mamur, unite with the Kara-Kum ; on the north their convex frontier line advances almost to the Merv oasis ; on the east they keep in great part about 400 to 1000 sazhen (2800 to 7000 feet) from the banks of the rivers Murg-ab and Kushk; and in some places they advance in the form of separate capes right up to the water.

Badkhyz has the same character, as also the country between the Borkhut Mountains and the Elbirin-kyr. From Pende, the oasis of the Saryks, the district gradually and very gently rises to the mountains Sefid-Kukh. Its irregularities are unimportant-hills between the Kushk and the Kash, 20 to 40 sazhen (140 to 280 feet) in height, in some places cut by shallow valleys drained by both affuents of the Murg-ab. The mountainous part of the district begins with the range of the Sefid-Kukh; 
there the ascent is very steep, and, according to Abbot and Grodekoff, the passes present considerable obstacles to traffic.

RIVERS.-Two great rivers with their affluents drain the whole country of South-west Turkomania. These are the Heri-rud and Murg-ab.

The Heri-rud takes its rise 350 versts (232 miles) east of Herat, at the point where the Sefid-Kukh and the Siya-Kukh unite. Its head stream bears the name of Jengel-ab, and only after its junction with the Tingal-ab does it begin to be called the Heri-rud, and enters on a broad valley everywhere suitable for tillage.

The great dam, situated a little above Herat, diverts a considerable part of the water of the rivers into canals for the irrigation of the Herat Valley, without dispute the richest in all Central Asia, to the south of the Amu-Darya (the ancient Oxus). At the present time the leading products are assafoetida, saffron, pistachio nuts, fruits of all kinds, grapes of various sorts, wheat, barley, clover. The silk-worm is reared to a considerable extent in the valley. Wood, or even bushes, however, exist only in places within the immediate neighbourhood of the Heri-rud; the slopes of the mountains are completely naked. Every settlement has rich orchards, but the only fuel is brushwood, brought from very distant parts. On the banks are luxuriant meadows, in which horses are pastured in great numbers-according to the Afghans, upwards of 40,000 . They form one of the principal exports of the Herat province to Persia : they are small, and of ordinary breed, but strong and hardy. There is also a considerable quantity of other cattle kept by the natives.

About 10 versts ( $6 \frac{1}{2}$ miles) lower down, before we reach Tir-pul, the valley contracts, and the Heri-rud advances very close to the heights of the south bank, and the road, both to Kafyr-Kala and to Gurian, continues in narrow defiles, sometimes on rather steep declivities.

At Tir-pul is a bridge built by Yar Mahomet Khan, forty sazhen (280 feet) long. The abutments and the arches are of brick; only the starlings are faced with strong stones, as in severe winters the ice is thick enough to support a horseman, and the "ice-gang" is generally of great force. When the water is high, the road from Herat to Meshed goes not via Kusan, but via Tir-pul, and thence along the south bank to Kafyr-Kala.

Near Kusan-the last Afghan settlement on the Heri-rud-the river turns almost directly to the north, and flows between low and cultivable banks as far as Pesh-robat. Thence it continues for about 20 versts (13 miles) through the defile which separates the Borkhut Mountains from the Kargala Mountains (the latter are the continuation of the former on Persian territory). After this the left bank is in great part only slightly hilly as far as Mount Peskemar, which approaches the river between Zurabad and Pul-i-Khatun. The heights of the right bank up to ZulfagarDerbend are in some parts 2 or 3 versts distant from the river, and further north, at Gyarm-ab-Derbend, approach close to it with very steep 
bluffs; there the valleys capable of irrigation are very rare, and are of quite limited extent. On the left bank the traces of unimportant sowings are visible only near Zur-abad, on the right bank about Zulfagar and Gyarm-ab-Derbend.

North from Pul-i-Khatun the left bank is bounded by the low and very gentle underfalls of the Khesar-Mesjid, on which are many places to which water for irrigation can be brought. The small hills of the right bank are a little higher; only for short distances about Shir-tepe, and Nouruz-abad there is a series of fields between the overflow of the river and the foot of the hills; about Kassab-Kale the hills give place to level ground suitable for tillage.

The Heri-rud from Kusan to. Pul-i-Khatun flows in great part in one channel from 15 to 20 sazhen (105 to 140 feet) broad. The water is usually high from the beginning of January to the end of, March; at that time the fords are very dangerous owing to the swiftness of the current, but as early as April one can cross in many places with a depth of not more than 4 feet. In the summer the water in the river rapidly diminishes, and in June and July crossing is possible everywhere, except where the steepness of the banks prevents it. In September, at the crossing from Kusan to Kafyr-Kale, MacGregor observed hardly any current with a depth of about 3 feet.

Further to the north, by August there is no current in the bed of the river : only here and there is preserved a reach of water, sometimes almost fresh, sometimes so brackish that horses drink it with reluctance. The bed everywhere consists of coarse pebbles, and the natives assert that when high water arrives the course of the river is continued, but only underground, and is then to be seen only in the deep parts of the bed; in any case an underground current exists, otherwise it is not possible to explain the short reaches of water which do not dry up all autumn. Water of such a depth, even on clayey soil, would dry up in two or three days. The current ceases, as already stated, somewhat to the north of Kafyr$\mathrm{Kale}$, and below that it begins. again only from Pul-i-Khatun, where the Kara-su falls into the Heri-rud, and receives a great increase from two abundant springs in the neighbourhood of Nouruz-abad : there there is so much water that it is everywhere conveyed by canals to the settlements of the Salors at Old Serakhs, and the supply is uninterrupted all the year round. Water appears again through the whole course of the river in November or December.

South of Pul-i-Khatun there are springs everywhere on the banks of the channel. The reaches in which the water is preserved in summer are so numerous that the traveller by the road along the Heri-rud may count on a good supply of water at any time of the year; but here and there the advance along the river is prevented by the mountains, which reach down close to the stream. In autumn it is everywhere possible to travel in the channel itself; when the water is high this is not the case. From Serakhs to Pul-i-Khatun the road is good on both banks. From this last point 
southward it is necessary to go by the west bank across Mount Peskemar to Zur-abad by a very difficult road, but on the Turkoman side travelling is practicable on level ground to the east of Mount Kelet-Koya, which extends its bluffs to the very bank of the river from Gyarm-ab-Derbend to the Zulfagar ravine. After that both banks again become fit for traffic. Where on the second occasion the mountains advance to the river, about 20 versts (13 miles) northward from the river Jam, a passage along the banks is quite impossible. In Serakhs people assert that in former times there was more water in the Heri-rud. There is no reason to believe that. Burnes, travelling through Serakhs in September 1832, found the bed of the stream completely dry, and so unimportant that he took it for the bed of a separate streamlet, Tajen, as if it took its rise in the neighbouring hills, and denied its connection with the river of Herat. The water of the Heri-rud, though turbid, is pleasant and wholesome.

At Pul-i-Khatun are the ruins of a bridge : about the date of its construction the Tekkes know nothing ; tradition only asserts that the bridge was built by a woman. Four of its arches exist at the present time. The fifth, and central, was destroyed by Medemii Khan, at the time of his expedition against Merv. The whole distance between the extremities of its

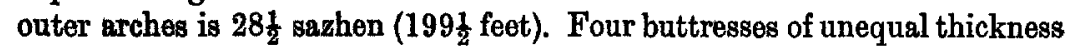
take up $9 \frac{1}{2}$ sazhen ( $66 \frac{1}{2}$ feet), and for the passage of the water there are five openings, taking the remaining 19 sazhen (133 feet). The first, from the Turkoman bank, measures 4 sazhen (28 feet); next are two of five sazhen each ; and lastly, on the Persian side, two of $2 \frac{1}{2}$ sazhen each. The breadth of the bridge is a little more than 2 sashen (14 feet). It is in good preservation; cracks are nowhere visible in the arches; and the restoration of the central arch would render it fit for the passage of beasts of burden across it. The buttresses are nowhere undermined; in some places their eurface has been worn away by the current up to the level of high water. Repairs could be generally accomplished without difficulty, as from the end of July to December the bridge is almost on dry ground: only under one or two arches are there two or three vershoks (each 1.75 of an inch) of water.

The continuation of the Heri-rud to the north and north-west from Serakhs is known by the name of Tejen. There is a current in this part of the river only during full water, when the stream is very deep, and in many places crossing is impossible. O'Donovan, in February 1881, crossed a little to the north of Kangaly-Guzer by swimming. On a previous occasion, in the middle of the same month, the Tejen at the Karry-bend dam had a breadth of about 12 sazhen (84 feet), and a depth of $5 \frac{1}{2}$ feet. Frequently the water there was deeper, and then for a month or a month and a half, the road passes through Alaman-Junguli, to which place the Tejen does not reach, but only the separate canals derived from it. Overflowings of the river, and inundations of those districts, take place only when the dam at Herat happens to burst. In the beginning of 1884 the dam at Karrybend and canals for irrigation of the surrounding country were restored. 
In summer the current in the Tejen ceases; in places it dries up completely, but in great part it consists of long lakes, fed, according to the opinion of the local inhabitants, by wells, but possibly also by underground prolongations of the streams Chacha, Meana, and Dushak, which end in marshes 15 to 20 versts from the Tejen. This opinion is based on the fact that the water in those lakes is cool and does not dry up in the course of the hottest summer, which could hardly be the case if they were only accumulations of the spring-tide water in the deep hollows of the bed of the Tejen.

The niver Murg-ab, rising in the north slope of the Sefid-Kukh, traverses a mountain district occupied by Khazare tribes, and about BalaMurg-ab descends into the plains of Southern Turkomania. From this bridge the right bank of the river consists of hills running near the watershed. Of ground suitable for tillage there is very little, and on the right bank the only fields are in the oasis of Pende. The slopes of the hills are for the most part gentle, and the road passing over them along the Murg-ab is of great service for traffic; only opposite Sary-yazi the hills descend almost vertically into the river by the bluffs of Kushle-Koya. Here, when the water is high, it is impossible to pass, and the road has to make a detour by the summit of the hills.

At Cape Kele-burun the clayey hills come to an end, and give place to sandy hills, which continue along the river to Iol-otan at the distance of one or two versts ( $\frac{1}{2}$ to $1 \frac{1}{4}$ miles) from the water; further north the sands surround the ruins of ancient towns near Merv, and advance on the road from this oasis to Bukhara.

The left bank from Bala-Murg-ab to Meruchak is bounded by hills in a fairly straight line ; then the valley widens, and in front of the junction of the Murg-ab and the Kushk lies a remarkably level triangle occupied by settlements of Saryks, and known by the name of Pende.

Northward to Iol-otan the left bank is bounded by sandy hills. Then the river flows in one or in several extraordinarily tortuous channels, with a total breadth of 10 to 20 sazhen; the banks are steep, often precipitous, with a height of 4 or more sazhen ( 28 feet). This first valley lies in a second of greater breadth only in certain places overflowed at high flood; it extends from 300 sazhen to 5 or more versts (2100 feet to 3 miles). The sands which bound this second valley on the west at times advance to the river in the form of capes, at times retire from it and form lake-like depressions, called by the natives keff; these areas are all adapted for tillage, and on many of them there are still traces of former irrigation in more peaceful times. Exceptionally good crops are furnished by the keffs when overflowed by the spring inundations.

The sands come nearest to the river between the Yungenly ford and Sary-yazi, and there, for a distance of about 10 versts, the road passes along the summit of the sand-hills. The Murg-ab flows in great part over a very easily disintegrated clayey bed; in consequence of the considerable descent of the country, the stream has a remarkably sinuous course, and undermines the left or lower bank. In many places the road 
making a great detour round some newly-formed bend, shows on what an extensive scale and how rapidly the undermining goes on. Such detours are especially frequent from Yungenly to Dash-Kepri, where great fissures are in many places visible in the cliffs along the banks; along the Kushk the canals nearest to its bank frequently fall in, and are removed further to the west.

The depth of the river at low water is 3 to 4 feet; in high water as much as 14 feet or more. High water occurs in spring, in the beginning of summer, and for brief periods after continued heavy rains in the mountains, during which the water rises very rapidly; in the spring of 1884 , at the ford near Kurjukli after heavy rain, the water rose $1 \frac{1}{2}$ feet in less than three hours. At low water in the whole river there are a great number of fords ; on the other hand, as long as high water lasts, there is no crossing by ford, and communication between the two banks is maintained almost exclusively by kayuks (large boats).

Except at Merv, where, up to the time of our capture of it, there were two very wretched bridges, there is only one bridge on the Murg-ab, at Iol-otan. It also is a very wretched construction; its opening is about 6 sazhen or 42 feet out of the 30 sazhen which at this place constitute the breadth of the river, the remaining portion is filled up with dams of earth and fascines. The opening is not large enough, and every year the high water carries off a part of the dams; the beams covering the two spans, 3 sazhen each, are removed to the bank at the approach of high water. In March of the present year I travelled by this bridge; by May it was carried away; it will be restored only in autumn. The depth of the river in the neighbourhood of the bridge is about 2 sazhen. A toll (badj) is charged for crossing by the bridge.

Kayuks (boats) are kept at Iol-otan and at Pende (Panj-deh). At this last point (where the breadth is 14 to 15 sazhen) the boats are guided by ropes stretched across the stream. The kayuks are made of short pieces of torrangi (willow) or pistachio wood fastened with wooden nails, and thoroughly caulked with rags of dressing-gowns; length of the kayuk is 2 sazhen, width 1 sazhen, depth about 1 arshin; it can convey at one time 4 horses or 20 men.

Both the Murg-ab and the Heri-rud contain great quantities of fish, but the Turkomans do not use them for food, owing to the belief that they cause fevers.

The Murg-ab furnishes better opportunities for settlement than the Heri-rud, and if at the present time the districts along the river are occupied by nomadic Turkomans only at three points, and the rest is complete desert, this arises from the disorder reigning in the steppes; along the whole bank, ruins of forts and caravanserais show that at one time it was thickly inhabited, and was the scene of busy traffic.

Of the affluents of the Murg-ab, the Kushk, the Kash, and the Kaisor are of importance for the life of the Turkomans.

The Kushk takes its rise on the northern slopes of the Sefid-Kukh, 
and begins to flow through mountainous regions unsuited for tillage. Below Chil-dukhter the valley widens, and throughout almost all its course, till it reaches the Murg-ab; at Dash-kepri the Saryks derive canals from the stream, and devote themselves to agriculture; the width of the cultivable belt is rarely more than 300 to 400 sazhen, and only reaches 6 versts at Kalei-mor.

The bottom of the Kushk below Kalei-mor is swampy and slimy, and consequently, although the depth of the water is for the most part not more than 1 arshin (28 inches), crossing by ford is possible only at a few definite points. Above Kalei-mor the bottom is gravelly, and crossing can be accomplished anywhere.

The water in the Kushk is fresh, but after long-continued droughts slightly salt; and on some occasions it dries up altogether. When this happens in early summer, it causes the destruction of the crops sown by the Turkomans. On the banks of the Kushk there are fresh springs, so that when the river dries up in its bed, there still remain certain reaches of slightly brackish water, sufficient for the supply of passing caravans.

Both tributaries of the Kushk (Gurlen-su and Khombou-su) have almost in their whole extent very salt water, unfit for irrigation; fresh springs occurring on the banks afford sufficient water for passing caravans. The Gurlen-su besides has, at the first, fresh water, and near the river of the same name, there are traces of somewhat extensive tillage. The Kash is in the same condition as the Kushk; when its stream dries up in the early part of the year, the same disasters follow. On the river Kaisor the ruins of Kalei-vali have quite recently been occupied by the Saryks.

SPRINGS AND WELLS.-The district to the south of Elbirin-kyr is better supplied with water, both in quantity and in quality, than the northern parts. The eastern slope, bordering the Heri-rud, is remarkably rich in springs; there springs of sweet water are frequent, though at present only sufficient for the supply of caravans; traces of tillage occur in rare instances (Keriz-Iliyas). It is very probable that the quantity of water in those localities may be considerably increased by exploration of the springs and the construction of kerizes (underground aqueducts). Eastward stretches a series of wells, in great part of fresh water, or with a very inconsiderable element of salt. The Borkhut Mountains and their slopes also abound with springs and wells. The springs are almost all fresh, but the soil is visibly impregnated with salt, and the streams issuing from the springs in a very short distance become completely salt and unfit for drinking.

As regards the supply of water, the northern part of the district, between the rivers, is very similar to the Kara-Kum. It possesses few wells, situated sometimes 80 versts (50 miles) apart; the water in them also has a certain quantity of salt, and for the classification of wells into fresh and salt the same rule is applied as in the desert, that is-those are called 
fresh from which the Turkomans provide themselves with water while travelling or nomadising, and those salt which are of no use to man for drinking purposes. Besides, it must be mentioned that there are no wells with bitter water, and that all those in the sands are available for cattle: sheep, camels, and even horses drink quite willingly of the salt water. All the sands of South-west Turkomania lie on a more or less permeable bottom ; takirs proper do not occur at all, and consequently there are no kak or rainpools, even after the heaviest rains.

Climate. - However comparatively unimportant the bairs of Elbirinkyr may be, this line of heights is sufficient to divide South-west Turkomania in its climatic aspect into two very dissimilar portions. The northern portion is in elimate quite like the Kara-Kum; with the ascent to the Borkhut Mountains, immediately after passing the Eibirin-kyr, constant and violent southern winds begin. As far as it is possible to judge by the periods which I have spent in those districts (one week in April and one week in August), the assertion of the Tekkes, that there is no good weather there, is quite credible. While on the plain it was perfectly quiet, near the Borkhut Mountains a strong gale was blowing. Clouds frequently came upon us, and on the northern slopes, on both journeys, we had rain-very small rain it is true, and scarcely wetting the road. On the southern slopes the winds moderated as we got away from the mountains, and half-way to Kusan they died away altogether. In Persia it was explained to me that the very name of Badkhyz, the district next to this portion of South-west Turkomania, and identical with it in climate, is derived from this condition of the atmosphere: bad means wind, and khosten (root khyz), to rise or get up. According to the Turkomans this weather lasts there the whole year; and those local winds, though not quite so strong, make life in Pende very irksome.

VeGETATION.-Vegetation in the main depends on the quality of the soil, and the abundance of water. Along the banks both of the Heri-rud and the Murg-ab (at the places overflowed by spring inundations), great quantities of poplars, mulberry trees, willows (torrangi), and bushes of various kinds occur, so dense that in many places it is not only impossible to approach the river on horseback, but even to make one's way on foot. Fodder for horses is everywhere in abundance, and of good quality. The trees growing there reach no inconsiderable dimensions, and this fact will explain the opinion of some travellers that timber existed on the banks of those rivers ( $H$. Alikhanoff reported the existence of timber-trees even on the road from Merv to Khiva). Though all the kinds that grow there are used, it is true, for roofing small places, for making small bridges across aryks, etc., they do not at all agree with the notion of timber which prevails in Russia. The wood of the willow and poplar are of no use for large erections or for furniture; for important works timber has to be brought from the Volga or from the Caspian; in the Trans-Caspian country there is none anywhere. 
In the district between the rivers, on the sandy clayey soil, mulberry trees occur only near the springs, and pistachio trees are scattered on all the hill slopes, for the most part singly, with considerable intervals between.

Both bushes and herbage grow badly on the kyrs, and thus, in comparison with the northern, the southern portion is very poorly supplied with them : only near the rivers can the pasture be considered really good; bushes are in general scarce. The northern part is quite different; the series of kyrs gives place to a soil with a preponderance of sand; very luxuriant herbage, which is known only to the Turkomans, covers the district. This part was the source of the wealth of the Saryks, the cause of the excellent quality of their herds. The Turkomans call it Misir: that means Egypt, and is employed in the same sense as we use the Land of Promise. There is not in this district such a burning up of the vegetation as occurs in the Kara-Kum; even the herbage dried by the summer is all excellent fodder for cattle. The Koyun-Kui wells are considered the centre of the best pastures.

Bushes are everywhere in abundance; growing ever closer and higher as we advance from the central steppes to the river Murg-ab, and near the river itself almost turning into woods. They are cut down only about the wells, and in settled places. Thus, in the whole oasis of Pende, and along the entire march to the north and south, there is neither bush nor tree. Fuel is conveyed thither out of the sands, and from Chemen-i-bid.

Mineral WealtrH.-Of the existence of any kind of mineral wealth in the Borkhut Mountains the Turkomans know nothing.

The Salt Lake, called Er-oilan or Duz, enjoys great repute in the surrounding countries. Duz means simply salt; but Er-oilan subsidence of the ground. There is a tradition that there was at one time a castle there which sank and gave place to two salt lakes. The hollow is 130 sazhen ( 910 feet) deep ; the shores, consisting of red clay, are partly vertical precipices, and partly flat expanses. The two lakes are separated by the high ground 70 sazhen (210 feet) above the bottom on which the road runs from Koyun-Kui to Ak-robat. On the south side of the lake are some kyrs standing apart, and visible from far. In the lakes above the salt, lies about $\frac{1}{2}$ arshin (14 inches) of water; pieces like millstones are raised from the bottom by levers. In the following year the portion grubbed up is filled again with salt, which the Turkomans assert is of undiminished quantity. The quality of the salt is excellent.

These lakes are utilised by all the Turkoman tribes inhabiting the surrounding districts; the people of Merv and Iol-otan use the western lake, the Saryks from Pende the eastern. The great road by which the Mervian salt caravans travel passes through Kele-burun and Koyun-Kui ; but it is so dangerous that the caravans must be large, and have strong escorts to protect them from the attacks of the Saryks or Persians. Besides this main route to Duz from Merv the sirdars know many smaller 
tracks by which they conduct small caravans. Last winter, after the arrival at Serakhs of the energetic Persian governor, Ali Merdan Khan, who took vengeance on the people of Merv for their brigandage by the pillage of a Tekke caravan near Koyun-Kui, traffic between Merv and Iol-otan and the lake ceased altogether, and the Mervians began to purchase salt from Pende by means of the people of Iol-otan. On the capture of Merv, and the consequent pacification of the district, the previous traffic was resumed. The Saryks of Pende also have paths known to themselves, and besides this two great roads; the first by the Kushk and onwards by Ak-robat-the longest, but with plenty of water; and the other without water, but the shortest, direct from Dash-Kepri to Duz.

Other tribes also supply themselves with salt from Er-oilan, but they do not venture thither themselves, and purchase it generally from the inhabitants of Pende. The Jemshidis procure it, not only for themselves, but also for sale in Herat, where it fetches a high price, as the salt obtained near this town in Afghanistan is of inferior quality. The inhabitants of Maimene also buy salt at Pende.

Communrcatron.-Since the Tekkes settled in Merv, and disorder took possession of the steppes, traffic in South-west Turkomania has been almost given up; even between Iol-otan and Pende, communication has been feebly maintained. The road from Pende to Herat by the Kushk, formerly a great caravan route, is now a scarcely visible foot-track. Within the district travel only well-armed caravans to the Er-oilan lakes, or brigands from Merv and Pende marching to pillage each other, or most frequently the Persians and Afghans. Trading caravans there are none. But these statements refer only to the most recent times; and I question if Rawlinson is right when he says that there never was a high-road there. ${ }^{1}$ The ruins of robats in Kungrueli and near the Khombou point to one of its directions, another was formed by the road through Ak-robat; in Gurlen, and near the pass of Karuan-ashan, still exist remains of fortifications and traces of cultivation.

The roads in their present condition are certainly mere sumpter tracks, but the general character of the district is in the highest degree favourable to the construction of good carriage roads or of a railway.

(To be completed in our next Number.)

\section{THE DISTURBANCES IN THE CANADIAN NORTH-WEST.}

THE following Memorandum, relating to the recent disturbances in the Canadian North-west, has been sent to us for publication by Sir Charles Tupper, C.B., High Commissioner for Canada :--

1 Proceedings of the Royal Geographical Society, January 1883, page 16: "I have stated that there never was a high-road through Badgheis, along the line of the Heri-rud." 


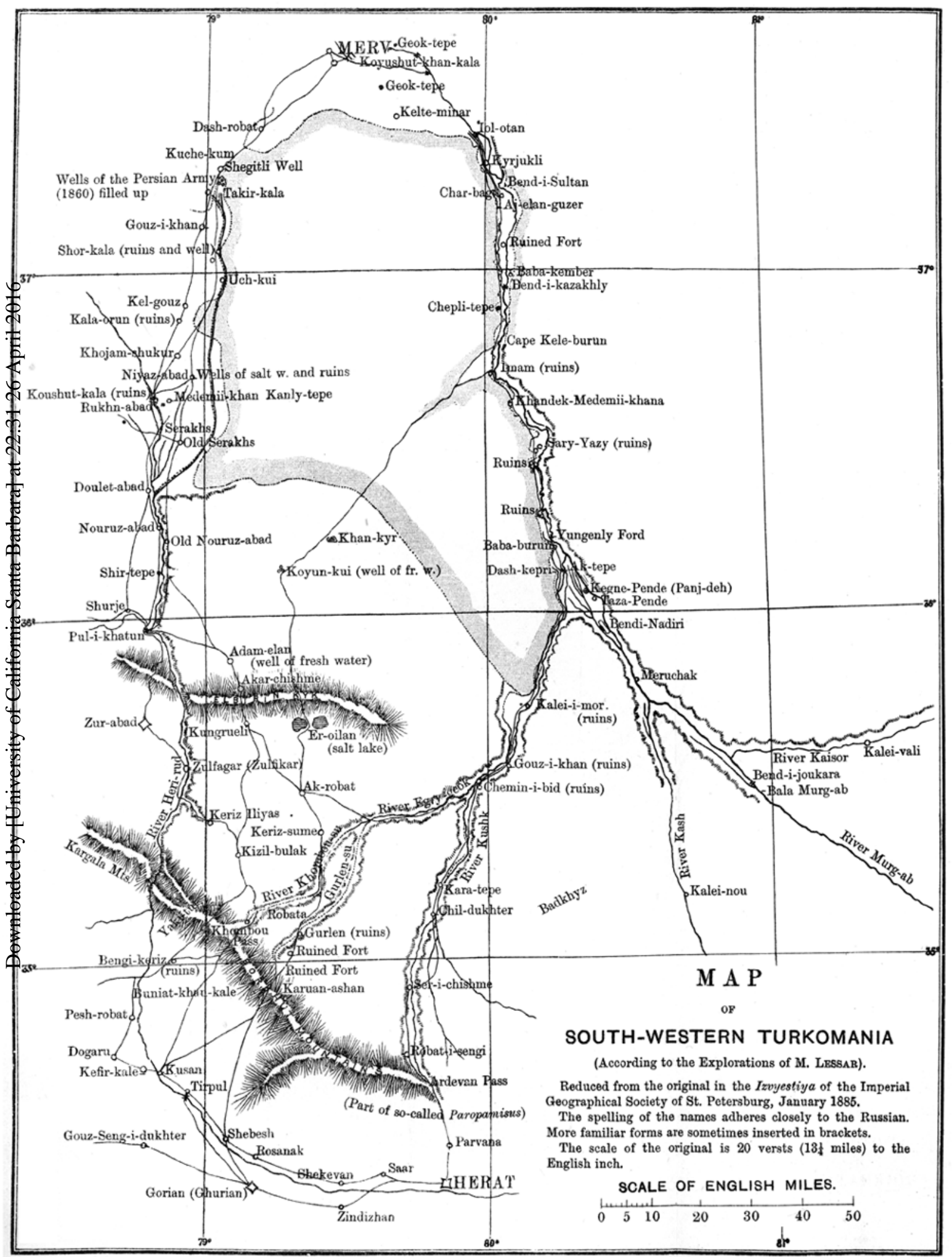

